\title{
FAKTOR YANG MEMPENGARUHI HASIL BELAJAR SISWA SEKOLAH DASAR DI KECAMATAN KOTA TAMBOLAKA
}

\section{FAKTOR'S AFFECTING STUDENT LEARNING OUTCOMES ELEMENTARY SCHOOL STUDENT'S IN DISTRICT TAMBOLAKA}

\author{
Heronimus Delu Pingge, Muhammad Nur Wangid \\ STKIP Weetebula, Universitas Negeri Yogyakarta \\ pinggeroni@yahoo.co.id, m_nurwangid@uny.ac.id
}

\begin{abstract}
ABSTRAK
Penelitian ini bertujuan untuk mengetahui hubungan kompetensi guru sekolah dasar dalam mendiagnosis kesulitan belajar siswa, memanfaatkan media belajar dan mengelola kelas dengan hasil belajar di kecamatan Kota Tambolaka, NTT. Penelitian ini adalah penelitian ex post facto. Populasi penelitian 241 orang guru. Sampel sejumlah 148 orang dengan teknik quota sampling. Pengumpulan data menggunakan metode kuisioner dan dokumentasi. Analisis data menggunakan teknik regresi linear sederhana dan ganda.Hasil penelitian menunjukkan sebagai berikut. (1) Hasil analisis regresi linearsederhana menunjukkan ada hubungan positif dan signifikan antara kompetensi guru sekolah dasardalam mendiagnosis kesulitan belajar siswa dengan hasil belajar siswa ( $<<0,05 ; \mathrm{R} 2: 24,8 \%$,); (2) Hasil

analisis regresi linear sederhana menunjukkan ada hubungan positif dan signifikan antara kompetensi guru sekolah dasar dalam memanfaatkan media belajar dengan hasil belajar siswa ( $<<0,05$; R2:20,1\%);(3) Hasil analisis regresi linear sederhana menunjukkan ada hubungan positif dan signifikan antarakompetensi guru sekolah dasar dalam mengelola kelas dengan hasil belajar $(\mathrm{p}<0,05 ; \mathrm{R} 2: 24,6 \%)$; dan (4)Hasil analisis regresi linear ganda menunjukkan ada hubungan positif dan signifikan antara kompetensiguru sekolah dasar dalam mendiagnosis kesulitan belajar siswa, memanfaatkan media belajar danmengelola kelas dengan peningkatan hasil belajar siswa (p<0,05; R2: 46,5\%).
\end{abstract}

Kata Kunci: diagnosis kesulitan belajar, media belajar, mengelola kelas, hasil belajar

\begin{abstract}
This study aimed to reveal the relationship between elementary school teacher's competencies in diagnosing student's learning difficulties, using media, and managing class and student's learning outcomes in Tambolaka,NTT. This research used a quantitative approach with ex post facto type. Thepopulation in this research was 241 teachers. The sample was 148 teachers with quota samplingtechnique. Data collection using questionnaire methods. Data analysis using linear simple and binaryregression techniques. The results are as follows. (1) there is a significant positive relationship betweenthe elementary school teacher's competency in diagnosing difficulties of students learning and student's

learning outcomes ( $\mathrm{p}<0.05 ; \mathrm{R} 2: 24.8 \%$ ) by the results of the simple linear regression analysis; (2) there isa significant positive relationship between the elementary school teacher's competency in using mediaand student's learning outcomes $(\mathrm{p}<0.05 ; \mathrm{R} 2: 20.1 \%)$ by the results of the simple linear $\mathrm{r}$
\end{abstract}


egressionanalysis; (3) there is a significant positive relationship between the elementary school teacher'scompetency in managing class and student's learning outcomes $(\mathrm{p}<0.05 ; \mathrm{R} 2: 24.6 \%)$ by the results ofsimple linear regression analysis; and (4) there is a significant positive relationship between theelementary school teacher's competency in diagnosing students learning difficulties, using media, andmanaging class and student's learning outcomes $(\mathrm{p}<0.05 ; \mathrm{R} 2: 46.5 \%)$ by results in a binary linearregression analysis.

Keywords: diagnosing students learning difficulties, using media, managing class, students learning outcomes

\section{Pendahuluan}

Dalam usaha membangun manusia Indonesia seutuhnya, faktor guru atau pendidik sangatlah penting karena guru bertugas untukmembangun manusia itu sendiri. Oleh karenaitu, diperlukan suatu kealihan sendiri dalammenjalankan tugas untuk mendidik pesertadidik, kealihan dalam menjalankan tugas seringdikenal dengan kompetensi. Kompetensi merupakan kemampuan, atau kapabilitas yang diterapkan dan menghasilkan kinerja (Performance) yang baik. Kemampuan tersebutmelekat pada individu (Suparman, 2012, p.64).

Kompetensi guru merupakan kemampuan atau kesanggupan guru dalam mengelola pembelajaran, sebagai pengetahuan, ketrampilan, dan nilai-nilai dasar yang direfleksikan dalam kebiasaan berpikir dan bertindak. Dengan demikian, kompetensi yang dimiliki oleh setiap guru akan menunjukkan kualitas guru yang sebenarnya. Hal ini berartibahwa guru dituntut mampu menciptakan danmenggunakan sikap positif dalam kegiatan pembelajaran. Guru yang berkompetensi atauguru profesional memahami akan apa yang dikerjakan. Guru harus memiliki pengetahuan yang luas tentang siswa, materi kurikulum atauilmu pengetahuan, organisasi kelas, dan pengusaan pendekatan pembelajaran.

Peraturan pemerintah RI Nomor 19 tahun 2005 tentang Standar Nasional Pendidikan BabVI pasal 28 menyatakan bahwa; (1) pendidik harus memiliki kualifikasi akademik dan kompetensi, sehat jasmani dan rohani, serta memiliki kemampuan mewujudkan tujuan pendidikan nasional, (2) kualifikasi akademik adalah tingkat pendidikan minimal yang harus dipenuhi oleh seorang pendidik yang dibuktikan dengan ijasah dan/atau sertifikat keahlian yang relevan sesuai ketentuan perundang-undangan, dan (3) kompetensi sebagai agen pembelajaran pada jenjang pendidikan dasar dan menengah meliputi kompetensi personal atau kompetensi kepribadian, kompetensi profesional, kompestensi pedagogik, dan kompetensi sosial.

Keempat kompetensi guru diatas, yakni kompetensi personal atau kompetensi 
kepribadian, kompetensi profesional, kompetensi pedagogik, dan kompetensi sosial bila dikaitkan dengan penelitian yang dilakukan mengenai kompetensi guru dalam mendiagnosis kesulitan belajar siswa, memanfaatkan media pembelajaran, dan mengelolah kelas terhadap hasil belajar siswa maka kompetensi guru yang dimaksud dalam penelitian tersebut merujuk pada kompetensi pedagogik. Karena digambarkan dalam kompetensi pedagogik guru harus mampu mengelola peserta didik yang meliputi pemahaman terhadap peserta didik.

Dalam memahami peserta didik maka guru akan mengetahui cara mengelola pembelajaran siswa atau dengan kata lain membelajarkan siswa. Pengelolaan pembelajaran siswa dimulai dari perencanaan dan pelaksanaan pembelajaran, dan mengevaluasi hasil belajar. Ketika guru merencanakan dan melaksanakan pembelajaran maka guru mampu menata ruang kelas,mengusai teori belajar, menciptakan iklim kelas yang kondusif, memotivasi siswa agar bergairah belajar, memberi penguatan verbal maupun non verbal, memberikan petunjukpetunjuk yang jelas kepada siswa, tanggap terhadap gangguan kelas, dan menyegarkan kelas jika kelas mulai lelah.

Dalam kegiatan pembelajaran di sekolah, guru akan berhadapan dengan karekteristik siswa yang beranekaragam. Ada siswa yang dapat menempu kegiatan belajarnya secara lancar dan tampa mengalami kesulitan, namun sisi lain tidak sedikit pula siswa yang justru dalam belajarnya mengalami berbagai kesulitan. Pada umumnya "kesulitan" merupakan suatu kondisi tertentu yang ditandai dengan adanya hambatan-hambatan dalam kegiatan mencapai tujuan. Kesulitan belajar dapat diartikan sebagai suatu kondisi dalam suatu proses belajar yang ditandai adanya hambatanhanbatan tertentu untuk mencapai hasil belajar. Hambatan-hambatan tersebut mungkin disadari dan munkin juga tidak disadari oleh orang yang mengalaminya.

Seorang guru yang profesional harus dapat mendiagnosis kesulitan belajar siswanya. Agar kegiatan ini dapat dilakukan, maka seorang guru juga dituntut untuk memiliki kemampuan melakukan diagnosis kesulitan belajar siswa.

Dalam dunia pendidikan istilah diagnosis merupakan istilah yang relatif baru. Harriman (Sugihartono,. dkk 2007, p.149), diagnosis adalah suatu analisis terhadap kelainan atausalah penyesuaian dari pola gejala-gejala. Jadi diagnosis merupakan proses pemeriksaan terhadap hal-hal yang dipandang tidak beres atau bermasalah pada individu. Diagnosis dengan kesulitan belajar merupakan kedua hal yang tidak dapat dipisahkan. Diagnosis merupakan upaya untuk menemukan faktorfaktor penyebab atau yang melatar belakangi timbulnya masalah belajar peserta didik. Dalam konteks proses belajar mengajar faktor-faktor penyebab 
kegagalan siswa dapat, bisa dilihat dari segi input, proses, ataupun out put.

Kesulitan belajar menunjuk pada sekelompok kesulitan yang dimanifestasikan dalam bentuk kesulitan nyata dalam kemahiran dan penggunaan kemampuan mendengarkan, bercakap-cakap, membaca, menulis, menalar dan ketidakmampuan dalam berhitung. Defenisi tentang kesulitan belajar di Indonesia belum ada yang baku. Pendidikan di Indonesia memandang siswa yang mendapatkan perolehan hasil belajar yang rendah diyakini mengalami kesulitan dalam belajar. seperti yang diungkapkan oleh Abduhrrahman (2012, p.5), "Pada guru umumnya memandang semua siswa yang memperoleh prestasi belajar rendah disebut siswa berkesulitan belajar".

Untuk mengetahui siswa yang mengalami kesulitan dalam belajar maka dibutuhkan yang namanya diagnosis kesulitan belajar. Diagnosis kesulitan belajar adalah upaya sistematis yang dilakukan oleh guru untuk memahami secara mendalam siswa yang mengalami kesulitan dalam belajar. Sugihartono dkk (2007, p.150) mendefinisikan secara utuh pengertian dari diagnosis kesulitan belajar, "diagnosis kesulitan belajar sebagai proses menentukan masalah atau ketidak-mampuan peserta didik dalam belajar dengan meneliti latar belakang penyebab dan atau dengan cara menganalisis gejala-gejala atau hambatan belajar yang nampak”. Dari pandangan tersebut dapat dipahami bahwa diagnosis kesulitan belajar merupakan suatu usaha atau kegiatan yang membutuhkan proses dalam menentukan masalah siswa dalam belajar dengan mengidentifikasi latar penyebabnya.

Peserta yang mengalami kesulitan belajar ditandai dengan karekteristik terntentu. Terdapat delapan karektesistik peseta didik yang mengalami kesulitan belajar oleh Watson, dkk (2014, pp.8-9), yakni: (a) Perception, peserta didik mengalami kesulitan dalam mengenali atau menafsirkan yang dirasakan, dilihat dan didengar; (b) Attention, merupakan ciri siswa yang mengalami kesulitan dalam memperhatikan atau fokus pada kegiatan pembelajan; (c) Memory,berkaitan dengan kesulitan siswa dalam mengelola informasi terlebih khusus menngelola informasi yang dibaca; (d) Processing Speed, merupakan kecakapan dalam memproses informasi. Akan ditemukan dalam kelas siswa yang cepat dalam memproses informasi dengan yang lamban. Hal tersebut dapat dilihat dari kecepatan mengusai materi pembelajaran; (e) Metacognition, peserta didik yang mengalami kesulitan belajar dengan ditandai mengalami kesulitan dalam membangun pemahaman baru atau membuat suatu kesimpulan dari yang dipelajari; (f) Language, peserta didik yang mengalami kesulitan dalam bahasa/fonologi; (g) Academic, peserta didk yang mengalami kesulitan belajar ditandai dengan penurunan 
pencapaian akademik. Dengan kata lain pencapaian hasil belajar peserta didik tidak sama dengan yang dicapai sebelumnya; dan (h) Social, peserta didik yang mengalami kesulitan belajar ditandai dengan kemampuan sosial dalam belajar yang menurun. Keberhasilan dalam belajar didukung dari rekan kelas atau hubungan sosial peserta didik.

Penyebab kesulitan belajar itu dapat dikelompokkan menjadi dua kelompok besar yaitu faktor yang berasal dari dalam diri pelajar (faktor internal) yang meliputi: kemampuan intelektual,afeksi seperti perasaan dan percaya diri, motivasi, kematangan untuk belajar, usia, jenis kelamin, kebiasaan belajar, kemampuan mengingat, dan kemampuan pengindraan seperti melihat, mendengarkan, dan merasakan. Sedang faktor yang berasal dari luar pelajar (faktor eksternal) meliputi faktor-faktor yang berkaitan dengan kondisi proses pembelajaran yang meliputi: guru, kualitas pembelajaran, instrumen atau fasilitas pembelajaran baik yang berupa hardware maupun software serta lingkungan, baik lingkungan sosial maupun lingkungan alam (Sugihartono,. dkk, 2007, p.155).

Untuk dapat mengetahui peserta didik yang mengalami kesulitan belajar Sugihartono, dkk (2007, pp.164-170) menjabarkan beberapa langkah-langkah mendiagnosis kesulitan belajar siswa sebagai berikut: a) Mengidentifikasi peserta didik yang diperkirakan mengalami kesulitan belajar; b) Melokalisasi Letak Kesulitan Belajar; c) Menentukan factor Penyebab kesulitan belajar; d) Memperkirakan alternatif bantuan; e) Menetapkan kemungkinan cara mengatasinya; dan f) Tindak lanjut. Dari keenam langkah tersebut dapat dijelaskan secara rinci dibawah ini.

Faktor lain yang menjadi sangat penting dalam pencapaian tujuan pembelajaran adalah memanfaatkan media pembelajaran oleh guru. Media sebagai alat bantu mengajar, membantu meng-komunikasikan materi pembelajaran lewat suatu alat atau media. Media adalah wadah dari pesan yang oleh sumbernya ingin diteruskan kepada sasaran atau penerima pesan tersebut. Dengan demikian, media pembelajaran adalah segala bentuk alat komunikasi yang dapat digunakan untuk menyampaikan informasi dari sumber atau pengajar keperta didik yang bertujuan merangsang mereka untuk mengikuti kegiatan pembelajanaran secara utuh.

Naz dan Akbar (2008, p.35) mendefinisikan media sebagai sarana komunikasi, yang asal kata dari bahasa Latin yang berarti "perantara". Perantara sumber dengan pesan dengan penerima pesan. Bila dikaitkan media dalam pembelajaran Naz dan Akbar mengatakan media merupakan sarana untuk menyampaikan pesan dan isi pembelajaran kepada peserta didik, untuk mencapai pengajaran yang efektif. 
Setiap individu mempunyai cara tersendiri dalam proses mereka belajar. Ada beberapa tipe pembelajaran, yaitu visual, auditori dan kinestetis. Pembelajar visual cenderung memilih kreativitas yang berkaitan dengan gambar, sehingga akan sangat baik bagi pendidik untuk dapat membantu pembelajara visual dengan menghubungkan warna dan bentuk, serta memberikan desain-desain yang eye-catching untuk siswa dengan diiringi pertanyaan dengan kalimat yang merangsang mata dan pikiran mereka. Pembelajar auditori akan belajar lebih dengan mendengarkan sesuatu, sehingga menjelaskan gagasan-gagasan secara lisan kepada temannya, diskusi dan meringkas informasi dengan kata-kata sendiri dapat membantu pembelajar tipe ini. Sedangkan pembelajar kinestetis lebih senang dengan kegiatan pembelajaran secara aktif. Mereka akan puas saat belajar dengan berpindah-pindah tempat. Namun guru tetap harus mengakrabkan mereka dengan keadaan yang mengharuskan mereka duduk sepanjang proses pembelajaran (Davis, 2010, pp.144).

Tabrani (Aqib, 2013, pp.75-76), mengemukan kemampuan dasar profesionalisme guru berkaitan dengan penggunaan media pembelajaran, yaitu : a) Mengenal, memilih dan menggunakan media; b) Membuat alat-alat bantu pelajaran sederhana; dan c) Mengunakan perpustakaan dalam proses pembelajaran.
Secara garis besar jenis media pembelajaran dalam tiga kelompok yakni, media visual, media audio, dan media audiovisual. Media visual merupakan media pembelajaran yang mempunyai sifat dapat dilihat seperti gambar,media grafis, model dan realia. Media audio merupakan media yang sifatnya dapat didengar dengan menggunakan indra pendengaran saja. Media ini mempunyai pesan auditif sehingga dapat meransang pikiran, persaan, perhatian, kreativitas, tapi menuntut daya menyimak. Media visual-audio merupakan gabungan media audio dan visual, yang sifatnya dapat didengar dan dilihat seperti video.

Selain kemampuan guru dalam mendiagnosis kesulitan belajar dan pemanfaatan media belajar untuk meningkatkan keberhasilan siswa dalam belajar ada faktor lain juga berpengaruh yaitu mengelolaan kelas. Mengelola kelas secara efektif akan memaksimal kesempatan pembelajaran murid.

Ruang kelas merupakan lingkungan pedagogis dimana komunikasi belangsung antara tenaga pengajar dan para siswa. Melaluikomunikasi timbal balik ini diusahakan tercapainya berbagai tujuan pendidikan, yang diantaranya semua tujuan intruksional umum dan khusus mendapatkan porsi perhatian yang cukup besar. Untuk itu perlu diciptakan suasana pendukung proses pembelajaran. Dalam hal ini guru memikul tanggung jawab yang besar, 
meskipun seiring dengan majunya perkembangan siswa sendiri menbangun suasana akademis pendukung atau penghambat. Menciptakan dan mempertahankan suasana di kelas yang membantu siswa untuk dapat berkonsentrasi dalam belajarnya dan dengan demikian memperoleh hasil yang maksimal yang dikenal dengan manajemen kelas atau pengolaan kelas.

Dapat dipahami bahwa konsep umum mengenai mengelolah kelas identik dengan kedisiplinan dan mengontrol prilaku. Mengelola kelas yang dimaksud adalah strategi untuk mengendalikan perilaku siswa, menanggapi gangguan, mengambil tindakan pada kenakalan siswa, memberi hadiah dan hukuman yang sesuai, dan pada umumnya untuk menjaga kenyamanan siswa dalam belajar dikelas.

Pengelolaan kelas yang efektif mempunya dua tujuan. Pertama: membantu murid menghabiskan waktu belajar dan mengurangi waktu akvititas yang tidak diorientasikan pada tujuan. Kedua: mencegah murid mengalami problem akademik dan emosional (Santrok , 2010, pp.558-559). Pengelolaan kelas yang baik dapat bertanggung jawab dan dapat memberikan suasana positif dengan sedikit konfilk, dimana energi terkonsentrasi dalam kegiatan dengan tujuan. Pada saat yang sama, anda menghapus banyak perjuangan yang terusmenerus yang habis dipakai begitu banyak, dan anda memiliki banyak waktu dan energi untuk bekerja dengan siswa.

Praktek pengelohan kelas yang baik dimulai dari hari pertama sekolah. Pengolahan kelas merupakan bagian penting dari peran kepemimpinan guru secara keseluruhan dan tidak dapat dipisahkan dari aspek-aspek lain dari ajaran. Perencanaan yang baik, penghargaan dan praktik hukuman, pengembangan kegiatan kelas, melibatkan siswa dalam pendekatan berpusat pada siswa, memperhatikan motivasi siswa, atau tugastugas pembelajaran yang berbeda. Semua elemenen dalam perspektif titik pengelolahan kelas untuk membangun lingkungan belajar yang positif untuk melibatkan siswa dalam belajar sehingga dapat meminimalkan masalah perilaku dan gangguan dalam pelajaran.

Apabila seorang pendidik yang berkompetensi akan dapat melakukan secara profesional tugas dengan baik seperti yang digambarkan diatas, yakni mendiagnosis kesulitan belajar siswa, menanfaatkan media pembelajaran dan mengelola kelas dengan baik dalam melakukan kegiatan belajar, maka tujuanpembelajaran secara khusus dan tujuanpendidikan secara umum akan dapat tercapai lewat hasil belajar yang baik.

Kenyataannya dilapangan atau di sekolah dasar pada kecamatan kota Tambolaka ditemukan bahwa guru belum cukup memahami manfaat dan melaksanakan betapa pentingnya 
mengamati atau mengobservasi siswa dalam belajar dengan keperluan untuk mendiagnosis siswa yang mengalami kesulitan dalam proses pembelajaran. Bila guru mengetahui siswa bermasalah dalam belajar tapi tidak semua guru melakukan pengulangan materi yang belum dipahami siswa dengan alasan mengejar target atau materi. Masih ada guru yang belum mengunakan media belajar. Sama halnya dengan pengolahan kelas, banyak guru ditemukan tidak mampu mendesain kelas secara optimal dan kurangnya komunikasi yang baik antar siswa dan guru. Fakta lain menunjukkan bahwa guru-guru sekolah dasar di kecamatan Kota Tambolaka, Kabupaten Sumba Barat Daya, propinsi Nusa Tenggera Timur belum melakukan kegiatan pembelajaran di sekolah secara maksimal disebabkan masih sangat kurang tenaga pendidik. Adapun tenaga pendidik yang ada belum memenuhi kualifikasi akademik sesuai dengan aturan tenaga pendidik disekolah dasar. Keterbatasan waktu dalam menyampaikan materi menjadi kendala bagi guru-guru dalam melaksanakan pembelajaran serta kurangnya kesadaran kedisiplinan waktu oleh guru.

Peserta dikatakan berhasil dalam belajar apabila siswa mencapai tujuan pelajaran. Dalam dunia pendidikan hasil belajar berkaitan dengan perubahan-perubahan pada diri siswa, baik yang menyangkut aspek kognitif, afektif dan psikomotorik. Susanto (2013, pp.6-11) mengkategorikan hasil belajar dalam tiga bagian; pertama, Pemahaman konsep (aspek kognitif) merupakan kemampuan untuk menerangkan dan mengiterprestasikan sesuatu. Sehingga bukan hanya sekedar mengetahui tapi betul-betul paham dengan mampu menberikan gambaran, contoh, dan penjelasan. Untuk dapat mengukur hasil belajar siswa berupa pemahaman konsep, guru dapat melakukan evaluasi produk. Winkel (2005, p.540) menyatakan bahwa melalui produk dapat diseliki apakah dan sejauh mana tujuan pembelajaran tercapai. Evaluasi produk dapat dilaksanakan dengan mengadakan berbagai macam tes, baik lisan maupun tulisan. Di Sekolah dasar diselenggarakan dalam bentuk ulangan, baik ulangan harian, ulangan semester maupun ulangan umum. Kedua, Ketrampilan proses (aspek psikomotor) merupakan ketrampilan yang mengarah kepada kemampuan mental, fisik, dan sosial yang mendasar sebagai penggerak kemampuan yang lebih tinggi dalam diri siswa. Ketrampilan yang dimaksud merupakan kemampuan menggunakan pikiran, nalar, dan perbuatan secara efektif termasuk kreativitas. Dan ketiga, Sikap siswa (aspek afektif) yang berkaitan dengan hasil belajar merupakan keterpaduan atau kekompakan antara mental dan fisik secara serentak. Jika mental saja yang dimunculkan, maka belum tampak secara jelas sikap seorang yang ditunjukkan. 
Berdasarkan uraian di atas, diduga; (a) Ada hubungan positif dan signifikan kompetensi guru Sekolah dasar dalam mendiagnosis kesulitan belajar siswa dengan hasil belajar siswa di kecamatan Kota Tambolaka, Kabupaten Sumba Barat Daya, NTT; (b) Ada hubungan positif dan signifikan kompetensi guru sekolah dasar dalam memanfaatkan media belajar dengan hasil belajar siswa di kecamatan Kota Tambolaka, Kabupaten Sumba Barat Daya, NTT; (c) Ada hubungan positif dan signifikan kompetensi guru sekolah dasar dalam mengelola kelas dengan hasil belajar siswa di kecamatan Kota Tambolaka, Kabupaten Sumba Barat Daya, NTT; dan (d) Ada hubungan positif dan signifikan secara bersama-sama kompetensi guru sekolah dasar dalam mendiagnosis kesulitan belajar siswa, memanfaatkan media belajar dan mengelola kelas dengan hasil belajar siswa di kecamatan Kota Tambolaka, Kabupaten Sumba Barat Daya, NTT.

\section{Metode Penelitian}

\section{Jenis Penelitian}

Penelitian ini merupakan penelitian dengan pendekatan kuantitatif dan menggunakan jenis ex post facto. Jenis penelitian ini dipilih dengan maksud untuk mengetahui data dan hubungan kompetensi guru sekolah dasar dalam mendiagnosis kesulitan belajar siswa $\left(\mathrm{X}_{1}\right)$, memanfaatkan media belajar $\left(\mathrm{X}_{2}\right)$ dan mengelola kelas $\left(\mathrm{X}_{3}\right)$ dengan hasil belajarsiswa (Y) di kecamatan Kota Tambolaka, Kabupaten Sumba Barat Daya, NTT.

\section{Waktu dan Tempat}

Penelitian Penelitian dilaksanakan di sekolah dasar di Kecamatan Kota Tambolaka, Kabupaten Sumba Barat Daya, NTT. Waktu penelitian mulai dari bulan Desember 2014 sampai dengan bulan Februari 2015.

\section{Subjek Penelitian}

Adapun populasi dalam penelitian ini adalah seluruh guru sekolah dasar yang terdapat pada sembilan belas sekolah dasar pada kecamatan Kota Tambolaka yang berjumlah 241 orang guru. Sampel pada penelitian ini adalah sebagian dari guru SD Kecamatan Kota Tambolaka Kabupaten Sumba Barat Daya yang diambil memalalui teknik sampel quota. Teknik sampel quota dilakukan dengan jalan menetapkan terlebih dahulu quota atau jumlah individu yang akan diteliti, adapun jumlah sampel sebanyak 148 guru.

\section{Instrumen dan Teknik}

Pengumpulan Data Teknik yang digunakan untuk mengumpulkan data adalah menggunakan berupa angket atau kuesioner dan dokumnetasi. Metode kuesioner dengan teknik skala Likert dibuat dalam bentuk checklist dengan alternative jawaban diberi skor 1, 2, 3, dan 4. Angket yang disusun bertujuan untuk mendapatkan data tentang kompetensi guru dalam mendiagnosis kesulitan belajar siswa $\left(\mathrm{X}_{1}\right)$, kompetensi guru 
dalam memanfaatkan media belajar $\left(\mathrm{X}_{2}\right)$, dankompetensi guru dalam mengelola kelas $\left(\mathrm{X}_{3}\right)$. Studi dokumentasi untuk mengumpulkan hasil belajar siswa kelas VI pada semester sebelumnya. Adapun maksud dari pengumpulan hasil belajar digunakan sebagai data variable hasil belajar siswa (Y).

\section{Teknik Analisis Data}

Analisis data menggunakan; (1) Deskripsi Variabel; (2) Uji Persyaratan Analisis regresi, Untuk analisis persyaratan regresi dengan uji normalitas, uji linearitas, uji multikolinearitas, dan uji heteroskedastisitas. Semua uji asumsi tersebut memenuhi syarat perhitungan regresi; (3) Uji Hipotesis Uji hipotesis menggunakan analisis regresi sederhana dan regresi ganda. Pada hipotesis I, II dan III dapat diperoleh persamaan regresi linear sederhana $\hat{Y}=a+b X_{1}$; $\dot{Y}=\mathrm{a}+\mathrm{b} \mathrm{X}_{2} ; \dot{Y}=\mathrm{a}+\mathrm{b} \mathrm{X}_{3}$, sedangkan pada hipotesis IVdapat diperoleh persamaan regresi ganda : $\dot{Y}=a+b 1 X_{1}+b 2 X_{2}+b 3 X_{3}$

\section{Hasil Penelitian Dan Pembahasan}

\section{Hasil Penelitian}

Berdasarkan data yang diperoleh dari 148 guru dapat deskripsikan variabel X1 menunjukkan rata-rata skor/mean 76,35, median skor 77,00, standar deviasi 7,86 dan untuk skor maksimum 94 sedangkan skor minimum adalah 48. Hasil hitungan selanjutnya bahwa kompetensi guru dalam mendiagnosis kesulitan belajar siswa yang termasuk kategori sangat baik berjumlah 71 orang guru $(47,97 \%)$, kategori baik 65 orang guru $(43,91 \%)$, kategori sedang 10 orang guru $(6,75 \%)$, kategori kurang baik 2 orang guru $(1,35 \%)$, dan kategori tidak baik 0 orang guru (0\%). Berdasarkan perhitungan diketahui bahwa rata-rata untuk kompetensi guru dalam mendiagnosis kesulitan belajar siswa adalah 76,35. Angka tersebut berada pada kategori baik, sehingga dapat dinyatakan bahwa kompetensi guru dalam mendiagnosis kesulitan belajar siswa di kecamatan Kota Tambolaka masuk dalam kategori baik.

Dapat dideskripsikan variabel X2 menunjukkan rata-rata skor/mean 56,28, median skor 57,00, standar deviasi 7,165 dan untuk skor maksimum 69 sedangkan skor minimum adalah 33. Hasil hitungan selanjutnya bahwa untuk kompetensi guru dalam memanfaatkan media belajar termasuk kategori sangat baik berjumlah 66 orang guru (44.59\%), kategori baik 35 orang guru $(23,64 \%)$, kategori sedang 45 orang guru $(30,40 \%)$, kategorikurang baik 2 orang guru $(1,35 \%)$, dan kategori tidak baik 0 orang guru (0\%). Berdasarkan perhitungan diketahui bahwa rata-rata untuk kompetensi guru dalam memanfaatkan media belajar adalah sebesar 56,28. Angka tersebut berada pada kategori baik, sehingga dapat dikatakan bahwa kompetensi guru dalam memanfaatkan media belajar di kecamatan Kota Tambolaka masuk dalam kategori baik. 
Berdasarkan data yang diperoleh dari 148 guru atau responden dapat deskripsikan variable $\mathrm{X}_{3}$ menunjukkan rata-rata skor/mean 78,97 , median skor 79,00, standar deviasi 4,414 dan untuk skor maksimum 88 sedangkan skor minimum adalah 66. Hasil hitungan selanjutnya bahwa untuk kompetensi guru dalam mengelola kelas termasuk kategori sangat baik berjumlah 142 orang guru (95.95\%), kategori baik 6 orang guru $(4,05 \%)$,kategori sedang 0 orang guru $(0 \%)$, kategori kurang baik 0 orang guru $(0 \%)$, dan kategori tidak baik 0 orang guru $(0 \%)$. Berdasarkan perhitungan diketahui bahwa ratarata untuk kompetensi guru dalam mengelola kelas adalah sebesar 78,97. Angka tersebut berada pada kategori sangat baik, sehingga dapat dikatakan bahwa kompetensi guru dalammengelola kelas di kecamatan Kota Tambolaka masuk dalam kategori sangat baik.

Dapat deskripsikan variabel hasil belajar (Y) menunjukkan rata-rata skor/mean 74.42, median skor 74.15, standar deviasi 3.780, dan untuk skor maksimum 84 sedangkan skor minimum adalah 63. Hasil hitungan selanjutnya bahwa untuk hasil belajar siswa termasuk kategori sangat baik berjumlah 66 siswa $(44,59 \%)$, kategori baik 82 siswa $(55,41 \%)$, kategori sedang 0 siswa $(0 \%)$, kategori kurang baik siswa (0\%), dan kategori tidak baik 0 siswa $(0 \%)$. Berdasarkan perhitungan diketahui bahwa rata-rata hasil belajar siswa adalah sebesar 58 .
Angka tersebut berada pada kategori baik, sehingga dapat dikatakan bahwa hasil belajar siswa pada semester satu di kecamatan Kota Tambolaka masuk dalam kategori baik.

Analisis data dihitung dengan bantuan program SPSS 19.0 untuk menguji pengaruh masing-masing variabel bebas terhadap variable terikat, yaitu regresi $\mathrm{X}_{1}$ terhadap $\mathrm{Y}$, regresi $\mathrm{X}_{2}$ terhadap $\mathrm{Y}$, regresi $\mathrm{X}_{3}$ terhadap $\mathrm{Y}$ (regresi liniear sederhana) dan pengaruh secara bersama-sama $\mathrm{X}_{1}, \mathrm{X}_{2}$ dan $\mathrm{X}_{3}$ terhadap $\mathrm{Y}$ (regresi linear ganda).

Uji hipotesis pertama menggunakan analisis regresi linear sederhana, pada tabel 1 dapat lihat nilai signifikansi regresi linear sederhana $X_{1}$ terhadap $Y$ sebesar 0,000 $(p<0,05)$. Hal ini berarti regresi linear sederhana $X_{1}$ terhadap $\mathrm{Y}$ adalah signifikan. Artinya $\mathrm{H}_{0}$ ditolak. Dengan demikian, dapat disimpulkan bahwa ada hubungan signifikan variabel kompetensi guru Sekolah dasar dalam mendiagnosis kesulitan belajar siswa $\left(\mathrm{X}_{1}\right)$ terhadap hasil belajar siswa (Y).

Tabel 1.Signifikansi Regresi $\mathrm{X}_{1}$ terhadap Y

\begin{tabular}{|c|l|r|l|ll|l|}
\hline \multicolumn{8}{|c|}{ ANOVAb } \\
\hline Model & $\begin{array}{l}\text { Sum of } \\
\text { Squares }\end{array}$ & $\begin{array}{l}\text { Mean } \\
\text { Square }\end{array}$ & F & Sig \\
\hline IRegresi & 519.859 & 1 & 519.859 & 48.032 & $.000^{\mathrm{a}}$ \\
Residual & 1580.169 & 146 & 10.823 & & \\
Total & 2100.027 & 147 & & & \\
\hline
\end{tabular}

a. Predictors: (Constant), X1

b. Dependent Variable: Y

Pada tabel 2 dapat dilihat koefisien determinasi (R2) sebesar 0,248. Hal ini berarti 
besarnya kontribusi variabel kompetensi guru dalam mendiagnosis kesulitan belajar siswa terhadap hasil belajar siswa sebesar $24,8 \%$, sisanya 75,2\% dipengaruhi oleh faktor lain.

Tabel 2. Kontribusi Variabel $\mathrm{X}_{1}$ terhadap $\mathrm{Y}$

\begin{tabular}{|l|l|l|l|l|}
\hline \multicolumn{5}{|c|}{ Model Summary } \\
\hline Model & R & $\begin{array}{l}\text { R.squ } \\
\text { are }\end{array}$ & $\begin{array}{l}\text { adjusted R } \\
\text { square }\end{array}$ & $\begin{array}{l}\text { std. error of } \\
\text { the estimate }\end{array}$ \\
\hline 1 & $.498 \mathrm{a}$ & .248 & .242 & 3.290 \\
\hline
\end{tabular}

a. Predictors: (Constant), X1

Diketahui koefisien regresi sebesar 0,239 dan konstanta sebesar 56,159 (lihat tabel 3), dengan demikian, arah regresinya positif. Selanjutnya, dapat dideskripsikan persamaan regresi sederhana sesuai dengan rumus persamaan regresi, yaitu $=56,159+0,239 X 1$. Artinya, semakin bertambah nilai Kopetensi guru dalam mendiagnosis kesulitan belajar siswa $\left(\mathrm{X}_{1}\right)$, maka semakin bertambah pula nilai hasil belajar siswa (Y).

Tabel 3. Koefisien Regresi $\mathrm{X}_{1}$ terhadap Y

\begin{tabular}{|l|l|l|l|l|l|}
\hline \multicolumn{7}{|c|}{ Coefficients $^{\mathbf{a}}$} \\
\hline Model & \multicolumn{2}{|l}{$\begin{array}{l}\text { Unstandardized } \\
\text { Coefficients }\end{array}$} & $\begin{array}{l}\text { Std.Coe } \\
\text { fficients }\end{array}$ & $\mathrm{t}$ & $\begin{array}{l}\text { si } \\
\mathrm{g}\end{array}$ \\
\cline { 2 - 6 } & $\mathrm{b}$ & Std.error & Beta & & \\
\hline C Constan & 56.159 & 2.649 & & 21.200 & .000 \\
X1 & .239 & .035 & .498 & 6.931 & .000
\end{tabular}

Uji hipotesis kedua menggunakan analisis regresi linear sederhana diperoleh nilai signifikansi regresi linear sederhana $\mathrm{X}_{2}$ terhadap Y sebesar 0,000 $(\mathrm{p}<0,05)$ (lihat tabel
4). Hal ini berarti regresi linear sederhana $X_{2}$ terhadap $\mathrm{Y}$ adalah signifikan. Artinya $\mathrm{H}_{0}$ ditolak Dengan demikian, dapat disimpulkan bahwa ada hubungan signifikan variabel kompetensi guru Sekolah dasar dalam memanfaatkan media belajar $\left(\mathrm{X}_{2}\right)$ terhadap hasil belajar siswa (Y).

Tabel 4. Signifikansi Regresi $X_{2}$ terhadap Y

\begin{tabular}{|c|c|c|c|c|c|c|}
\hline \multicolumn{7}{|c|}{ ANOVAb } \\
\hline Model & $\begin{array}{l}\text { Sum of } \\
\text { Squares }\end{array}$ & $\overline{\mathrm{Df}}$ & $\begin{array}{l}\text { Mean } \\
\text { Square }\end{array}$ & $F$ & & Sig. \\
\hline Regression & 422.480 & 1 & $\frac{1}{422.480}$ & 36.769 & $.000^{\mathrm{a}}$ & \\
\hline Residual & 1677.547 & 146 & 11.490 & & & \\
\hline Tntal & 31 วกกา & $1 \Delta 7$ & & & & \\
\hline
\end{tabular}

a. Predictors: (Constant), X2

b. Dependent Variable: Y

Besarnya koefisien determinasi (R2) sebesar 0,201 (lihat tabel 5). Hal ini berarti besarnya kontribusi variabel $\mathrm{X}_{2}$ terhadap $\mathrm{Y}$ sebesar $20,1 \%$, sisanya 79,9\% dipengaruhi oleh faktor lain yang tidak masuk dalam penelitian ini.

Tabel 5. Kontribusi Variabel $X_{2}$ terhadap $Y$

\begin{tabular}{|l|l|l|l|l}
\hline \multicolumn{5}{c}{ Model Summary } \\
\hline Model & $\mathrm{R}$ & $\begin{array}{l}\mathrm{R} \\
\text { Square }\end{array}$ & $\begin{array}{l}\text { Adjusted } \\
\text { R Square }\end{array}$ & $\begin{array}{l}\text { Std. Error of } \\
\text { the Estimate }\end{array}$ \\
\hline 1 & $.449 \mathrm{a}$ & .201 & .196 & 3.390 \\
\hline
\end{tabular}

a. Predictors: (Constant), X2

Diketahui koefisien regresinya sebesar 0,237 dan konstanta sebesar 61,105 (Lihat table 6), dengan demikian arah regresinya positif. Selanjutnya, dapat dideskripsikan persamaan regresi sesuai dengan rumus persamaan regresi, yaitu $=61,105+0,237 \mathrm{X}_{2}$. Artinya, semakin bertambah nilai kompetensi guru dalam 
memanfaatkam media belajar $\left(\mathrm{X}_{2}\right)$, maka semakin bertambah pula nilai hasil belajar siswa $(Y)$.

Tabel 6. Koefisien Regresi $\mathrm{X}_{2}$ terhadap $\mathrm{Y}$

\begin{tabular}{|l|l|l|l|l|l|}
\hline \multicolumn{7}{|c|}{ Coefficients $^{\mathbf{a}}$} \\
\hline Model & $\begin{array}{l}\text { Unstandardized } \\
\text { Coefficients }\end{array}$ & $\begin{array}{l}\text { Std.Coeffi } \\
\text { cients }\end{array}$ & $\mathrm{t}$ & $\begin{array}{l}\mathrm{Si} \\
\mathrm{g} .\end{array}$ \\
\cline { 2 - 7 } & $\mathrm{b}$ & Std. Error & Beta & & \\
\hline 1 (Constant & 61.105 & 2.214 & & 27.601 & .000 \\
X2 & .237 & .039 & .449 & 6.064 & .000 \\
\hline
\end{tabular}

a. Dependent Variable: Y

Uji hipotesis ketiga menggunakan analisis regresi linear sederhana, diperoleh nilai signifikansi regresi linear sederhana $\mathrm{X} 3$ terhadap Y sebesar 0,000 ( $<<0,05)$ seperti yang tampak pada tabel 7. Hal ini berarti regresi linear sederhana $\mathrm{X} 3$ terhadap $\mathrm{Y}$ adalah signifikan. Artinya $\mathrm{H}_{0}$ ditolak. Dengan demikian, dapat disimpulkan bahwa ada pengaruh positif signifikan kompetensi guru dalam mengelola kelas $\left(\mathrm{X}_{3}\right)$ terhadap variabel hasil belajar siswa (Y).

Tabel 7. Signifikansi Regresi $\mathrm{X}_{3}$ terhadap Y

\begin{tabular}{|c|c|c|c|l|l|}
\hline \multicolumn{7}{|c|}{ ANOVAb } \\
\hline Model & $\begin{array}{l}\text { Sum of } \\
\text { Squares }\end{array}$ & Df & $\begin{array}{l}\text { Mean } \\
\text { Square }\end{array}$ & F & Sig. \\
\hline 1Regression & $\begin{array}{c}517.218 \\
\text { Residual }\end{array}$ & 1 & 517.218 & 47.709 & $.000^{\mathrm{a}}$ \\
& 1582.809 & 146 & 10.84 & & \\
Total & 2100.027 & 147 & 1 & & \\
\hline
\end{tabular}

a. Predictors: (Constant), X3

b. Dependent Variable: Y

Besarnya koefisien determinasi $\left(\mathrm{R}^{2}\right)$ sebesar 0,246 (lihat tabel 8). Hal ini berarti besarnya kontribusi variabel $\mathrm{X}_{3}$ terhadap $\mathrm{Y}$ sebesar $24,6 \%$, sisanya $75,4 \%$ dipengaruhi oleh faktor lain.
Tabel 8. Kontribusi Variabel $\mathrm{X}_{3}$ terhadap $\mathrm{Y}$

\begin{tabular}{|l|l|l|l|l|}
\hline \multicolumn{5}{|c|}{ Model Summary } \\
\hline Model & $\mathrm{R}$ & $\begin{array}{l}\mathrm{R} \\
\text { Square }\end{array}$ & $\begin{array}{l}\text { Adjusted } \\
\text { R Square }\end{array}$ & $\begin{array}{l}\text { Std. Error of } \\
\text { the Estimate }\end{array}$ \\
\hline 1 & $.496 \mathrm{a}$ & .246 & .241 & 3.293 \\
\hline
\end{tabular}

a. Predictors: (Constant), $\mathrm{X}_{3}$

Diketahui koefisien regresinya sebesar 0,425 dan konstanta sebesar 40,861 (lihat table 9), dengan demikian arah regresinya positif. Selanjutnya, dapat dideskripsikan persamaan regresi sesuai dengan rumus persamaan regresi, yaitu $\hat{y}=40,861+0,425 \mathrm{X}_{3}$. Artinya, semakin bertambah nilai kompetensi guru dalam mengelola kelas $\left(\mathrm{X}_{3}\right)$, maka semakin bertambah pula nilai hasil belajar siswa (Y).

Tabel 9. Koefisien Regresi $X_{3}$ terhadap $Y$

\begin{tabular}{|c|c|c|c|c|c|}
\hline \multicolumn{6}{|c|}{ Coefficients $^{\mathrm{a}}$} \\
\hline \multirow[t]{2}{*}{ Model } & \multicolumn{2}{|c|}{$\begin{array}{l}\text { Unstandardized } \\
\text { Coefficients }\end{array}$} & \multirow{2}{*}{$\begin{array}{l}\begin{array}{l}\text { Std. } \\
\text { Coefficient } \\
\text { s }\end{array} \\
\text { Beta }\end{array}$} & \multirow[t]{2}{*}{$\mathrm{t}$} & \multirow[t]{2}{*}{ Sig } \\
\hline & $\mathrm{b}$ & Std. Error & & & \\
\hline 1 (Constant & 40.861 & 4.866 & & 8.397 & .000 \\
\hline $\mathrm{X} 3$ & .425 & .062 & .496 & 6.907 & .000 \\
\hline
\end{tabular}

a. Dependent Variable: Y

Uji Hipotesis Keempat menggunakan uji regresi linear ganda dilakukan untuk mengetahui apakah variabel $\mathrm{X}_{1}, \mathrm{X}_{2}$, dan $\mathrm{X}_{3}$ secara bersama-sama mempunyai pengaruh yang positif signifikan terhadap variabel bebas (Y). Pada tabel 10 diperoleh nilai signifikansi regresi linear ganda variabel $\mathrm{X}_{1}, \mathrm{X}_{2}$, dan $\mathrm{X}_{3}$ terhadap $Y$ sebesar $0,000(p<0,05)$. Hal ini berarti regresi linear variabel $\mathrm{X}_{1}, \mathrm{X}_{2}$, dan $\mathrm{X}_{3}$ terhadap $\mathrm{Y}$ adalah signifikan. Artinya $\mathrm{H}_{0}$ ditolak. Dengan demikian, dapat disimpulkan bahwa ada pengaruh positif signifikan variabel 
kompetensi guru dalam mendiagnosis kesulitan belajar siswa $\left(\mathrm{X}_{1}\right)$, pemanfaatan media belajar $\left(\mathrm{X}_{2}\right)$, mengelola kelas $\left(\mathrm{X}_{3}\right)$ terhadap variabel hasil belajar siswa (Y).

Tabel 10. Signifikansi Regresi Linear Ganda

\begin{tabular}{|l|lc|l|l|ll|l|}
\hline \multicolumn{8}{|c|}{ ANOVAb } \\
\hline Model & $\begin{array}{l}\text { Sum of } \\
\text { Squares }\end{array}$ & Df & $\begin{array}{l}\text { Mean } \\
\text { Square }\end{array}$ & F & Sig. \\
\hline Regression & 976.696 & 3 & 325.565 & 41.734 & $.000^{\mathrm{a}}$ & \\
Residual & 1123.331 & 144 & 7.801 & & & \\
Total & 2100.027 & 147 & & & & \\
\hline
\end{tabular}

a. Predictors: (Constant), X1, X3, X2

b. Dependent Variable: $Y$

Pada tabel 11 dapat diperoleh nilai koefisien determinasi ( $\mathrm{R}$ Square) sebesar 0,465. Oleh karena itu, kontribusi kompetensi guru dalam mendiagnosis kesulitan belajar siswa $\left(\mathrm{X}_{1}\right)$, pemanfaatan media belajar $\left(\mathrm{X}_{2}\right)$, mengelola kelas $\left(\mathrm{X}_{3}\right)$ secara bersama-sama maka semakin bertambah pula nilai hasil belajar siswa (Y) sebesar 46,5\%, sisanya $53,5 \%$ dipengaruhi oleh faktor lain.

Tabel 11. Kontribusi variabel $X_{1} \quad X_{2}, X_{3}$ terhadap Y

\begin{tabular}{|l|l|l|l|l|}
\hline \multicolumn{5}{|c|}{ Model Summary } \\
\hline Model & $\mathrm{R}$ & $\begin{array}{l}\mathrm{R} \\
\text { Square }\end{array}$ & $\begin{array}{l}\text { Adjusted R } \\
\text { Square }\end{array}$ & $\begin{array}{l}\text { Std. Error of } \\
\text { the Estimate }\end{array}$ \\
\hline 1 & $.682 \mathrm{a}$ & .465 & .454 & 2.793 \\
\hline
\end{tabular}

a. Predictors: (Constant), X1, X3, X2

Tabel 12. Koefisien Regresi $X_{3}$ terhadap $Y$

\begin{tabular}{|l|l|r|r|l|l|}
\hline \multicolumn{7}{|c|}{ Coefficients $^{\text {a }}$} \\
\hline \multirow{2}{*}{ Model } & \multicolumn{2}{l}{$\begin{array}{l}\text { Unstandardized } \\
\text { Coefficients }\end{array}$} & $\begin{array}{l}\text { Std.Coeffi } \\
\text { cient }\end{array}$ & $\mathrm{t}$ & Sig. \\
\cline { 2 - 7 } & $\mathrm{b}$ & Std. Error & Beta & & \\
\hline 1(Constant & 28.230 & 4.496 & & 6.279 & .000 \\
X3 & .344 & .055 & .402 & 6.284 & .000 \\
X2 & .089 & .037 & .170 & 2.430 & .000 \\
X1 & .183 & .032 & .381 & 5.693 & .000 \\
\hline a. Dependent Variable: Y
\end{tabular}

Sedangkan koefisien regresi $\mathrm{X}_{1}$ sebesar 0,183 , koefisien regresi $\mathrm{X}_{2} \quad 0,089$, dan arah regresi $\mathrm{X}_{3}$ sebesar 0,344 dan konstanta sebesar 28,230 (lihat tabel 12), dengan demikian, semua arah regresinya positif. Selanjutnya, dapat dideskripsikan persamaan regresi sesuai dengan rumus persamaan regresi, yaitu $=28,230+0,183 \mathrm{X} 1+0,089 \mathrm{X} 2+$ 0,344X3. Hal ini dapat dimaknai bahwa semakin bertambah nilai kompetensi guru dalam mendiagnosis kesulitan belajar siswa $\left(X_{1}\right)$, pemanfaatan media belajar $\left(\mathrm{X}_{2}\right)$, mengelola kelas $\left(\mathrm{X}_{3}\right)$ secara bersama-sama maka semakin bertambah pula nilai hasil belajar siswa (Y).

\section{Pembahasan}

Hasil penelitian yang berkaitan dengan hubungan kompetensi guru dalam mendiagnosis kesulitan belajar siswa dengan hasil belajar siswa menunjukkan adanya hubungan yang positif dan signifikan serta kontribusinya sebesar 24,8\%. Diperoleh persamaan regresi sederhana variabel $X_{1}$ yaitu $=56,159+0,239 X 1$. Dapat dimaknai bahwa semakin bertambah nilai Kompetensi guru dalam mendiagnosis kesulitan belajar siswa $\left(X_{1}\right)$ maka semakin bertambah pula nilai hasil belajar siswa $(\mathrm{Y})$.

Dari data tersebut diatas membuktikan apabila pendidik mampu mengidentifikasi peserta didik yang mengalami hambatan dalam belajar serta memberikan perlakuan yang sesuai maka akan dapat mempengaruhi hasil belajar 
peserta didik. Dapat dibuktikan dari penelitian yang dilakukan oleh Soleh, A., dkk (2014), terdapat pengaruh prestasi belajar matematika pada siswa yang mengalami kesulitan belajar secara signifikan antara siswa yang mengikuti pembelajaran dengan model pembelajaran remedial dengan siswa yang mengikuti pembelajaran dengan model pembelajaran konvensional.

Dalam melaksanakan kewajiban sebagai guru maka para guru perlu diperlengkapi dengan pengetahuan, sikap, dan ketrampilan dalam hubungannya dengan mengidentifikasi kesulitan belajar, sebab-sebabnya dan penanganan masalah belajar siswa tersebut. Diperlukan ketrampilan tersebut karena adanya perbedaan-perbedaan kemampuan, kecerdasan, bakat, minat dan latar belakang fisik serta sosial masing-masing murid, maka kemajuan belajar murid dalam satu kelas mungkin tidak sama. Ada murid yang cepat, biasa dan ada yang lambat. National Center for Learning Disabilities atau disingkat NCLD (2014, p.8), Hampir semua responden (90\%) mengetahui bahwa melanggar hukum bagi pendidik untuk memberhentikan seorang peserta didik karena ketidakmampuan belajar. ini artinya bahwa peserta didik mendapat hak yang sama dalam memperoleh ilmu pengetahuan serta dibantu bila mengalami kesulitan bukan ditinggalkan atau dibiarkan bila mengalami kesulitan belajar.
Peserta didik yang lambat perkembangan akademik tersebut disekolah sering terjebak dalam kegagalan disekolah. Keterlambatan akademik merupakan kesulitan belajar peserta didik mengarah pada keterlambatan penguasaan kemampuan akademik, ketrampilan dan perolehan informasi baru. Kesulitan belajar siswa akan mempengaruhi seluruh aspek perkembangan siswa termasuk keberhasilan belajar. Seperti dalam catatan NCLD (2014, p.16), Siswa dengan kesulitan belajar mendapat nilai yang lebih rendah ketimbang yang tidak mengalami kesulian belajar dan siswa yang mengalami kesulitan belajar biasanya tahan kelas.

Melihat efek dari siswa yang mengalami kesulitan belajar seperti yang digambarkan oleh NCLD diatas Mavuso (2014, pp.457-460), dalam penelitian yang dilakukan pada guru untuk mengetahui strategi guru dalam memfasilitasi proses belajar siswa yang mengalami kesulitan belajar ditemukan empat strategi untuk mendukung belajar proses belajar siswa yang mengalami kesulitan belajar yakni: a). Give learners extra work, translate the work and re-teach as a learning support strategy; $b$ ). Differentiation as a strategy to provide learning support; c). Assessment of learners a strategy to provide learning support; and d). Peer support a strategy to provide learning support.

Hasil penelitian yang berkaitan dengan 
hubungan kompetensi guru sekolah dasar dalam memanfaatkan media belajar dengan hasil belajar siswa menunjukkan adanya hubungan yang signifikan dan positif serta kontibusinya sebesar 20,1\%. Diperoleh persamaan regresi sederhana variabel X2 yaitu $=61,105+0,237$ $\mathrm{X} 2$. Artinya, semakin bertambah nilai kompetensi guru dalam memanfaatkam media belajar (X2), maka semakin bertambah pula nilai hasil belajar siswa (Y).

Dari hasil tersebut menunjukkan bahwa kemampuan guru dalam memanfaatkan media belajar sangat berpengaruh pada pencapaian hasil belajar siswa. Pembuktian lainnya diungkapkan dalam penelitian survey yang dilakukan oleh Zohrani (2009), pada variabel Kemampuan menggunakan media pembelajaran oleh guru menyatakan ada pengaruh yang signifikan pada hasil belajar SDN di kecamatan Selong, Lombok timur. Pengaruh variabel media pembelajaran oleh guru kelas I-V sebesar $10,8 \%$, sedangkan pada guru kelas VI pengaruh penggunaan media pembelajaran terhadap hasil belajar siswa sebesar 26,2\%.

Dalam menggunakan media pembelajaran diharapkan pendidik dapat menggunakan media yang bervariasi sesuai dengan karekteristik anak, materi pembelajaran dan lingkungan atau budaya siswa. Penelitian tindakan kelas yang dilakukan oleh Riyanto dan Suryani (2007), pada siswa kelas V SD
Negeri Rambutan pada matapelajaran IPA menunjukkan bahwa penggunaan media yang bervariasi dapat menumbuhkan keaktivan siswa dalam belajar yang berdampak pada peningkatan hasil belajar siswa. Menurut KBYU Eleven (2010, p.5), kegiatan belajar siswa melibatkan tiga hal pokok yakni View, Read, and Do. Supaya ketiga hal tersebut dapat terlaksana dengan baik maka guru harus memahami cara peserta didik dalam memproses informasi dalam memori. Akan ditemukan peserta didik yang gaya Auditory learners, Visual learners, and Kinesthetic (or hands-on). Pemahaman gaya belajar tersebut oleh guru sangat penting. Akan ada Peserta didik menonjol dalam satu gaya belajar tapi bisa juga ada peserta didik yang memiliki ketiga gaya belajar diatas. Pemahaman peserta didik tersebut menuntut guru untuk bisa memanfaatkan berbagai media belajar yang bervariasi dalam kegiatan belajar mengajar.

Tennyson (2010, p.7), Interaksi peserta didik dengan media dan lingkungan belajar menjadi penting dalam akhir 1990-an dan terus menjadi fokus peningkatan selama dekade pertama abad ke-21. Menjadi fokus dalam dunia pendidikan karena peserta didik sebagai individu yang aktif membangun pengetahuan.

Hal tersebut sesuai dengan pandangan konstruktivis belajar adalah bahwa aktif, mandiri, mengarahkan pada tujuan, dan 
penemuan ataupun eksplorasi dari lingungan untuk mengkontruksi pengetahuan.

Penggunaan media belajar dalam kegiatan belajar mengajar akan membantu guru dan siswa untuk mencapai tujuan pembelajaran yang yang dibuktikan dengan hasil belajar yang memuaskan. Karena secara garis besar tujuan media belajar ada tiga bagian yaitu tujuan memotivasi, menyampaikan informasi dan tujuan instruksional. Tujuan motivasional untuk menghibur dan membangkitkan minat peserta didik. Tujuan informasional biasanya digunakan untuk mempresentasikan suatu informasi dalam hal ini menyampaikan materi pembelajaran. Tujuan instruksional dimaksudkan untuk menumbuhkan minat yang diberikan melalui pelibatan peserta didik secara psikis atau aktifitas lain yang berkaitan dengan media pembelajaran yang digunakan.

Hasil penelitian yang berkaitan dengan hubungan kompetensi guru dalam mengelola kelas dengan hasil belajar siswa menunjukkan adanya hubungan yang positif dan signifikan serta kontribusinya sebesar $24,6 \%$. diperoleh persamaan regresi sederhana variabel $X_{3}$ yaitu $=40,861+0,425 \times 3$. Artinya, semakin bertambah nilai kompetnsi guru dalam mengelola kelas (X3), maka semakin bertambah pula nilai hasil belajar siswa (Y).

Hasil diatas membuktikan bahwa kemampuan guru dalam mengelola kelas sangat membantu siswa dalam mencapai hasil belajar yang diinginkan. Pembuktian lainnya diungkapkan dalam penelitian survey yang dilakukan oleh Zohrani (2009) pada variabel Kemampuan mengelola kelas oleh guru menyatakan ada pengaruh yang signifikan pada hasil belajar SDN di kecamatan Selong, Lombok timur, besarnya pengaruh pengelolaan kelas oleh guru pada kelas I-V 23,7\% dan kelas VI $28,9 \%$.

Marzano (2013, pp.130-133), menggambarkan bahwa mengelola kelas berada dalam posisi penting dalam kegiatan guru untuk membelajarkan siswa dalam mencapai hasil belajar yang diharapkan. Marzano mengumpulkan bukti tentang pentingnya pengelolaan kelas dengan mengkaji riset yang dilakukan oleh Wang dan Walberg pada tahun 1993. Pengelolaan kelas mendapat sorotan yang sangat kuat dalam riset tersebut. Terdapat 228 variabel yang dapat mempengaruhi hasil belajar siswa. Dari daftar variabel tersebut diberikan kepada 134 ahli pendidikan untuk menilai dampak dari setiap variabel. Berdasarkan tangggapan para ahli, pengelolaan kelas atau manajemen kelas mendapat peringkat pertama. Hal tersebut cukup masuk akal, apabila pengelolaan kelas yang buruk akan dapat mengambat belajar siswa atau tidak dapat meningkatkan hasil belajar siswa. 
Temuan Wang dan Walberg diatas tentang pengelolaan kelas dikuatkan dengan penelitian yang dilakuan oleh Oyinloye (2010, pp.310-311) pada para guru tentang persepsi manajemen kelas dengan hasil belajar. digambarkan para guru percaya bahwa lingkungan terorganisir dan kelas dikelola dengan baik akan meningkatkan hasil belajar mengajar. Sebab kelas dengan perilaku siswa yang mengganggu dapat menyebabkan perkembangan akademik kelas rendah dan cendrung memiliki nilai lebih rendah ketika melakukan penilaian.

Kegiatan guru untuk mengelola kelas dengan baik menurut Evertson (Oliver., Joseph., \& Daniel,, 2011, p. 7) ada tujuh, yaitu:

(1) organizing the classroom; (2) planning and teaching rules and procedures; (3) managing student work and improving student accountability; (4) maintaining good student behavior; (5) planning and organizing; (6) conducting instruction and maintaining momentum; and (7) getting the year off to a good start.

Pengelolaan kelas termasuk dalam persiapan bahan pembelajaran, pengaturan waktu, ketrampilan mengajar oleh guru, mengelompokkan murid dalam belajar, ketrampilan mengakhiri pembelajaran dan mengontrol prilaku belajar siswa. Pengolaan kelas mengarah pada peran guru untuk menata pembelajaran secara kolektif atau klasikal dengan cara mengelola perbedaan-perbedaan kekuatan individual menjadi sebuah aktivitas belajar bersama. Fasilitas yang disediakan dikelas memungkinkan siswa belajar, tercapainya suasana kelas yang memberikan kepuasan, suasana disiplin, nyaman, dan penuh semangat sehingga terjadi perkembangan intelektual emosional dan sikap serta apresiasi pada siswa. Bila kelas yang dikelola dengan baik oleh guru tidak hanya meningkatkan pembelajaran yang berarti, tetapi juga membantu mencegah perkembangan problem emosional dan akademik.

Hasil penelitian yang berkaitan dengan hubungan kompetensi guru dalam mendiagnosis kesulitan belajar siswa (X1), pemanfaatan media belajar (X2), mengelola kelas (X3) terhadap variabel hasil belajar siswa (Y) menunjukkan hubungan yang positif dan signifikan serta kontribusinya sebesar 46,5\%. Diperoleh persamaan regresi linear ganda adalah $=28,230+0,183 \mathrm{X} 1+0,089 \mathrm{X} 2+$ $0,344 X 3$. Hal ini dapat dimaknai bahwa semakin bertambah nilai kompetensi guru dalam mendiagnosis kesulitan belajar siswa (X1), pemanfaatan media belajar (X2), mengelola kelas (X3) secara bersama-sama maka semakin bertambah pula nilai hasil belajar siswa (Y).

Dalam melaksanakan tugas guru 
dituntut memiliki kemampuan secara metodologis dalam hal perencanaan. Indikator kinerja guru dalam penyelenggaraan pendidikan ditandai dengan adanya pengelolaan kelas, dan sumber belajar, menggunakan metode pembelajaran, dapat memahami karekteristik peserta didik baik dari aspek seperti moral, emosional, dan intelektual. Hal ini akan berimplikasi bagi guru untuk memahami cara belajar peserta didik, perkembangan belajar peserta didik, dan masalah-masalah belajar yang dihadapi oleh peserta didik.

Dalam mengajar peserta didik tidak dilakukan oleh siapa saja. Mengajar menurut Frankena (Jaiyeoba, 2011, p.5) melibatkan suatu ilmu pengetahuan yang disampaikan kepada orang yang kurang berpengalaman atau belum dewasa melalui pendekatan sadar dan terencana. Tentunya dalam dunia pendidikan yang melakukan kegiatan pengajaran adalah guru. Guru yang mempunyai kompetensi untuk melakukan kegiatan proses belajar mengajar. Guru berkompetensi adalah guru yang kemampuan untuk memenuhi kebutuhan dan tuntutan profesi guru dalam jumlah yang cukup dan menggunakan pengetahuan, keterampilan, dan sikap yang tercermin dalam kinerja guru.

Guru yang berkompetensi merupakan guru yang berkualitas. Hanushek, Kain dan Rivkin (Jaiyeoba, 2011, p.6) menegaskan bahwa kualitas guru merupakan faktor yang paling penting disekolah untuk menjelaskan kualitas sekolah. Kualitas guru di sekolah- sekolah menentukan kualitas produk atau prestasi yang diperoleh siswa lewat hasil belajar yang didapatkan. Studi yang dilakukan oleh Jaiyeoba (2011) di Negeria pada guru sekolah dasar menjabarkan empat point yang mendukung kualitas pendidikan sekolah dasar yakni: a). Guru sekolah dasar harus memahami tujuan sekolah dasar; b) pesepsi guru terhadap profesi keguruan; c) kepedulian terhadap peserta didik; dan d) memahami masalah yang menghalangi kerja guru.

Pemahaman tujuan sekolah dasar menurut Jaiyebo diatas adalah: a) guru memahami bahwa pendidikan dasar bertujuan untuk melek angka dan kemampuan komunikasi yang efektif, b) Pendidikan dasar adalah untuk meletakkan dasar yang kuat untuk berpikir ilmiah dan reflektif, c) Pendidikan dasar memberikan pendidikan kewarganegaraan, d) Pendidikan dasar diharapkan untuk membentuk karakter dan mengembangkan sikap yang sehat dan moral pada anak, e) Pendidikan dasar berkembang pada anak kemampuan untuk beradaptasi dengan lingkungannya berubah, dan f) Pendidikan dasar memberikan anak sebagai alat dasar untuk kemajuan pendidikan lebih lanjut. Hal yang berkaitan dengan pesepsi guru terhadap profesi keguruan yakni, apakah guru memandang bahwa mengajar adalah profesi 
yang menguntungkan atau merugikan. Bila guru memandang mengajar sebagai profesi yang mulia maka guru akan memperoleh kepuasaan dari profesinya. Sedangkan bila guru melihat profesi guru tidak menguntungkan maka dapat dilihat dari kerja yang tidak teratur serta akan melakukan pekerjaan alternatif.

Kepedulian terhadap peserta

didik menurut Jaiyebo ditandai dengan perasaan puas dari keunggulan belajar siswa yang diperoleh, artinya tertarik untuk terus memanjukan hasil belajar siswa baik pada aspek kognitif (membaca, berhitung dan menulis), aspek afektif (cara berpakaian dan karakter) dan psikomotorik. Bentuk kualitas pendidikan dasar yang terakir yakni memahami masalah yang menghalangi kerja guru. Point ini lebih merujuk kebijakan yang harus diambil oleh lembaga pendidikan (pemerintah) dalam mendukung dan menghargai profesi guru dalam bentuk pembiayaan atau gaji yang sesuai, menyediakan sarana dan prasaran pendukung kegiatan belajar mengajaran, mengatasi kelas yang padat, dan peningkatan profesionalisme guru dalam bentuk pelatihan atau sejenisnya.

\section{Simpulan dan Saran}

\section{Simpulan}

Berdasarkan hasil analisis data dan pembahasan, maka dapat disimpulkan bahwa (1) Ada hubungan positif kompetensi guru SD dalam mendiagnosis kesulitan belajar siswa dengan hasil belajar siswa di Kecamatan Kota Tambolaka. Kontribusinya sebesar 24,8\%; (2) Ada hubungan positif kompetensi guru SD dalam memanfaatkan media belajar dengan hasil belajar siswa di Kecamatan Kota Tambolaka. Kontribusinya sebesar 20,1\%; (3) Ada hubungan positif kompetensi guru SD dalam mengelola kelas dengan hasil belajar siswa di Kecamatan Kota Tambolaka. Kontribusinya sebesar 24,6\%; dan (4) Ada hubungan positif kompetensi guru SD dalam mendiagnosis kesulitan belajar siswa, memanfaatkan media belajar, dan mengelola kelas dengan hasil belajar siswa di Kecamatan Kota Tambolaka. Kontribusinya sebesar 46,5\%.

\section{Saran}

Berdasarkan kesimpulan diatas, dapat disampaikan saran sebagai berikut; (1) Bagi guru-guru SD Sekecamatan Kota Tambolaka supaya dapat meningkatkan layanan pembelajaran dengan baik supaya kompetensi yang berkaitan dengan mendiagnosis kesulitan belajar siswa, pemanfaatan media belajar dan mengelola kelas terus ditingkatkan; (2) Bagi para Kepala Sekolah SD di kecamatan Kota Tambolaka untuk dapat memperhatikan dan mengevaluasi kegiatan para guru terkaitan dengan kegiatan mendiagnosis kesulitan belajar siswa, pemanfaatan media belajar dan mengelola kelas; (3) Bagi Dinas Pendidikan 
dan Kebudayaan Kabupaten Sumba Barat Daya dan pengelola pendidikan swasta. Diharapkan dapat melakukan pelatihan dan melengkapi sumber daya yang belum sempurnadisekolah untuk mendukung kerja guru yang berkaitan dengan kegiatan mendiagnosis kesulitan belajar siswa, pemanfaatan media belajar dan mengelola kelas. Kegiatan supervise jug perlu dilakukan untuk memantau aktivitas guru di kelas atau di sekolah.

\section{Daftar Pustaka}

Abdurrahman, M. (2012). Anak Berkesulitan Belajar: Teori, Diagnosis dan remidiasinya. Jakarta: Rineka Cipta

Aqib, Z. (2013). Model-model, Media, dan Strategi pembelajaran Kontekstual (Inovatif). Bandung: Yrama Widya

Davis, R.W. (2010). Creative Teaching (Strategi Pengajaran Kreatif). Jakarta: Esensi Erlangga Group

Depdiknas. (2005). Peraturan Pemerintah RI Nomor 19 Tahun 2005, tentang Standar Nasional Pendidikan.

Jaiyeoba, A. O. (2011). Primary School Teachers' Knowledge of Primary Education Objectives and Pupils Development. The African Symposium: An online journal of the African Educational Research Network. Vol. 11, No. 1, 4-11

KBYU. (2010). Benefits of Media and the Learning Triangle: Learn how to combine children's television, books, and hands-on activities to support your child's learning. Diambil pada tanggal 18 Maret 2015, dari www.kbyutv.org. pdf
Marzano, R.J. (2013). Seni dan ilmu Pengjaran. Jakarta: PT Indeks

Mavuso, M, F. (2014). Strategies for Facilitating Learning Support Processes. What can Teachers do Support Learners with Specific Learning Difficulties?. Mediterranean Journal of Social Sciences, Vol 5 No 2, 455-461

National Center for Learning Disabilities. (2014). The State of Learning Disabilities Facts, Trends and Emerging Issues. New York: National Center for Learning Disabilities

Naz, A. A., \& Akbar, R.A (2008). Use of Media for Effective Instruction its Importance: Some Consideration. Journal of Elementary Education A Publication of Deptt. of Elementary Education IER, University of the Punjab.Vol. 18, 35-40

Oliver, R.M., Joseph H.W., \& Daniel J. R. (2011). Teacher classroom management practices: effects on disruptive or aggressive student behavior. The Campbell Collaboration, Last updated: June 2011, 1-56

Oyinloye, G.O. (2010). Primary school teachers' perception of Classroom Management And Its Influence On Pupils' Activities. European Journal of Educational Studies, 2(3), 305-312

Riyanto,. \& Heny, S. (2007). Variasi media dalam meningkatkan aktivitas dan hasil belajar sains. Vorum Pendidikan, Volume 26 No 2, 120-127

Santrock, W, J. (2010), Psikologi Pendidikan. Jakarta: Salemba Humanika

Soleh, A,. Made C,. \& Ni. K,W. (2014). Pengaruh Pembelajaran Remedial 
Sugihartono,.dkk. (2007. Psikologi Pendidikan. Yogyakarta: UNY Press

Suparman, Atwi. (2012). Desain Instruksional Modern: pandauan para pengajar dan innovator pendidikan. Jakarta: Erlangga

Susanto, A. (2013). Teori belajar dan pembelajaran di sekolah dasar. Jakarta: Kencana prenada media group
Watson, S,. Dkk. (2014). Guidelines for Educating Students with Specific Learning Disabilities (versi Pdf). Diambil pada tanggal 11 Desember 2014, dari http://www.doe.virginia.gov.Winkel, W, S. (2005). Psikologi Pengajaran. Yogyakarta: Media Abadi

Zohrani. (2009). Determinasi guru terhadap hasil belajar siswa kelas VI di Sekolah Dasar Negeri di kecamatan Selong kabupaten Lombok Timur. Tesis magister, tidak diterbitkan, Universitas Negeri Yogyakarta, Yogyakarta. 